\title{
The Effect of Profitability and Tax Avoidance on Profit Management and Its Impact on Company Value
}

\author{
Lawe Anasta
}

\begin{abstract}
This study aims to examine and assess the influence of Profitability and tax avoidance to Firm Value to Implementation of Earnings Management as an intervening variable (Empirical Study on Manufacturing Companies Listed on Indonesia Stock Exchange for the period 2013 - 2017). The data used in this research is secondary data in the form of annual report and audit report as of December 31. The research data was taken from the official website of Indonesia Stock Exchange and the website of each company. The population in this research were 225 companies with a study period of 2013 to 2017 . The sample used as many as 45 manufacturing companies listed on the Indonesia Stock Exchange (BEI) in 2013 - 2017. The samples using purposive technique. These results indicate that profitability and tax avoidance had a positive significant effect on firm value. Profitability had a positive significant effect on earning management. Tax avoidance have no influence on earning managements. Earning management has no influence on firm value. Earning management does not mediate the relationship between profitability and tax avoidance with an intervening test pass.
\end{abstract}

Keywords: Profitability, Tax Avoidance, Firm Value, Earning Managements

DOI: $10.7176 / \mathrm{EJBM} / 11-27-04$

Publication date:September $30^{\text {th }} 2019$

\section{INTRODUCTION}

The establishment of a company has a goal to maximize profits so that it can prosper shareholders. Maximizing profits can increase the value of the company. Shareholders will give assignments to financial management to maximize company value. The management as the manager in the company has more information about the company and is ahead of the shareholders. The problem between managers and shareholders is called agency problem. The existence of agency problems will lead to not achieving the company's financial goals, namely increasing the value of the company by maximizing shareholder wealth (Verawaty et al. 2017). The following is a sample of share price data from 5 (five) companies listed on the Indonesia Stock Exchange in 2013 - 2017 :

TABLE CLOSING PRICE

\begin{tabular}{cccccc}
\hline Kode & $\mathbf{2 0 1 3}$ & $\mathbf{2 0 1 4}$ & SHARE PRICE & $\mathbf{2 0 1 6}$ & $\mathbf{2 0 1 7}$ \\
ADES & 2000 & 1375 & $\mathbf{2 0 1 5}$ & 1000 & 885 \\
ASII & 6800 & 7425 & 6000 & 8275 & 8300 \\
INDF & 6600 & 6750 & 5175 & 7925 & 7625 \\
SMGR & 14150 & 16200 & 11400 & 9175 & 9900 \\
INTP & 20000 & 25000 & 22325 & 15400 & 21950 \\
\hline
\end{tabular}

Sumber: www.finance.yahoo.com (data diolah: 2018)

With the table of stock values presented in the five companies above, most companies experienced fluctuations, but there were also companies that continued to experience a decline in their share prices. The fluctuating company value makes it difficult for investors to predict the value of the company in the future, so investors will consider the decision to invest in the company more. Company value can be influenced by the level of profitability and tax avoidance and earnings management. Earnings management is closely related to the level of profit or company performance. This is because the level of profits obtained is associated with management performance, so that it will have an impact on the attitude of managers who always want to show good performance and encourage them to do some engineering. Although these earnings management practices are often considered prevalent for the accounting profession, the implementation strategy is a secret for company managers. Research that explains profitability and tax avoidance on firm value is done by Yorke et al. (2016) stating that there is an influence of profitability and tax voidance on profits generated by the company. Research conducted by Arhdum, et al (2017) which states that earnings management affects the value of the company. However, the results of research conducted by Verawaty (2017) show that earnings management does not affect the value of the company.

\section{LITERATURE REVIEW}

\section{a. Agency Theory}

This theory was put forward by Michael Jensen and Wiliam H. Meckling (1976), explaining that agency relationships occur when a person or more (principal) employs another person (agency) to provide a service and then delegate decision-making authority. Agency theory has a focus on the relationship between two actors who 
have different interests, namely between agents and principals. This theory also provides an overview of the separation between management and shareholders. This separation aims to achieve effectiveness and efficiency in managing the company by hiring the best agents in managing the company. There is a possibility that the agent may be concerned with his personal interests at the expense of the principal, but on the other hand the principal wants a high rate of return from invested resources (Ghozali and Adityamurti, 2017).

b. The value of the company

Company value can be interpreted as the views and assessments of investors on the success of $\backslash$ the company to utilize all the resources owned by the company (Putri et al 2015). High corporate value is the desire of the owners of the company, because with high value will show the prosperity of shareholders is also high. Tobin's Q ratio is considered to be able to provide the most accurate information to assess the company, because in Tobin's $\mathrm{Q}$ includes all aspects, not just shares. The higher the Tobin's Q value the better because it shows that the company will have the possibility of good growth in the future (Putri et al 2015).

c. Profit management

Earnings management is a management effort to maximize or minimize profits, including income smoothing in accordance with the wishes of management. Earnings management is one of the factors that can reduce the credibility of financial statements because it can add bias and disrupt financial statement users who trust the figures of the engineered profits (Asih, 2014).

d. Profitability

Kasmir (2017) explains that profitability ratios are ratios to assess a company's ability to seek profits. This ratio also gives a measure of the effectiveness of a company's management. This is indicated by profits generated from sales and investment income. The point is the use of this ratio shows the efficiency of the company. The use of profitability ratios can be done by using comparisons between various components that exist in financial statements, especially financial statements and profit and loss. Measurements can be made for several operating periods. The aim is to see the development of the company in a certain time span, both decreases and increases, while looking for the causes of these changes.

e. Tax Avoidance

Broadly speaking, according to Dyreng et.al. (2008), tax avoidance can be interpreted as a reduction in the company's explicit tax liability. On the basis of this understanding, Tax avoidance shows a strategy for a sustainable tax plan which is a legal activity and other more aggressive activities that will be closer to illegal activities in the eyes of the law (Syarifudin and Kurniawan, 2017).

\section{LOGICAL FRAMEWORK}

1. The Relationship of Profitability to Corporate Values

Companies that have gone public have the main goal of increasing the prosperity of the owners or shareholders. To achieve these main objectives, financial management will seek maximum profits or maximum profits. Agency theory appears when principals or shareholders want large profits, motivating management to report maximum profits so that management's performance is seen by the principals. The results of this study are in line with the research of Wulandari and Suryono (2018), Normayanti (2017) and Sari and Priyadi (2016) who found that profitability has a positive effect on firm value.

$\mathrm{H} 1$ = Profitability affects the value of the company.

2. Effect of Tax Avoidance on Company Values

When a company is able to minimize expenditures for tax purposes, it means that fewer expenses are incurred by the company. Expenses are a deduction in getting company profits. The smaller the burden incurred by the company, the greater the profit gained by the company. Agency theory arises when management seeks to reduce taxes by avoiding taxation to obtain high corporate value while the principal does not want tax avoidance because it is considered financial report manipulation (Ghozali and Adityamurti, 2017). Supported by the research results of Syafruddin and Kurniawan (2017), Pradnyana and Noviari (2017) that there is a positive effect of tax avoidance on firm value.

$\mathrm{H} 2=$ Tax avoidance affects the value of the company.

3. Effect of Profitability on Profit Management

According to Bringham and Houston (2009) in Murni (2017) profitability is the end result of a number of company management policies and decisions. The higher ROA can indicate the better company performance, which is seen from the maximization of profits that can be generated by the company. If it is associated with agency theory where to meet the principal demands of maximizing profits, it is very likely that the manager of earnings management will be practiced. The study was supported by research conducted by Kamil and Ariyani (2017) and Murni (2017) that profitability proved to have a positive effect on earnings management. H3 = Profitability affects earnings management

4. Effects of Tax Avoidance and Profit Management

Tax avoidance is an effort made by management to reduce corporate tax burden. Rahman, et al. (2013) stated 
that one of the motivations of earnings management is minimizing taxes. The higher the profit of a company, the greater the tax burden that must be paid, thus motivating management to make earnings management so that the tax burden paid is reduced. Agency theory arises when the principal wants high profits so that the company's performance looks good so that management is motivated to report high profits so that management performance looks good in the eyes of the principal by doing tax avoidance.

H4 = Tax avoidance affects earnings management.

5. Effect of earnings management on company value

Earnings management is an act of managing profits according to what certain parties want, especially by management. Managers as managers of the company know more about the internal information and prospects of the company in the future than the owners (shareholders) giving rise to information asymmetry. Asymmetry between management and owner provides an opportunity for managers to conduct earnings management to increase company value. Supported by the Arhdum study, et al (2017) and Febyani and Devie (2017) which state that earnings management influences the value of the company.

H5 = Earnings management affects the value of the company.

6. Effect of Profitability on Corporate Values Through Profit Management

ROA is a measure of profitability from the perspective of shareholders. Return on Assets shows management's success in maximizing returns to shareholders. The higher Return on Assets addresses the performance of good companies so that the company has a good level of efficiency, so the stock price will also increase, and will affect the value of the company. Agency theory arises when management strives to increase returns on investment from shareholders to obtain high corporate value while the principal does not want financial statement manipulation because it will make the profit generated is not real.H6 = Profitability affects the value of the company through earnings management.

7. Effect of Tax Avoidance on Corporate Values Through Profit Management

Tax avoidance is an effort made by management to reduce corporate tax burden. Rahman, et al. (2013) stated that one of the motivations of earnings management is minimizing taxes. The company considers taxes as a burden. Agency theory arises when management seeks to reduce taxes by making tax avoidance to obtain high corporate value while the principal does not want tax avoidance because it is considered financial report manipulation. Tax avoidance carried out by management can also provide information asymmetry to investors (Ghozali and Adityamurti, 2017).

$\mathrm{H} 7$ = Tax avoidance affects the value of the company through earnings management.

Based on this description the logical framework of this research hypothesis are explained in the figure:

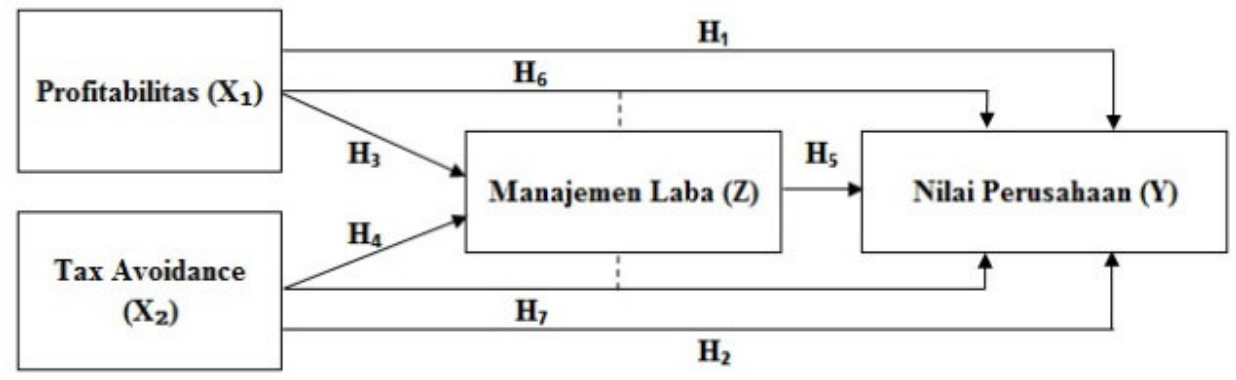

\section{METODOLOGY ANALYSIS}

When the research conducted by the author to conduct this research is in 2017 by taking financial data or financial statements on the Indonesia Stock Exchange from 2013-2017 sourced from the website www.idx.co.id and www.sahamok.com. This study uses causal research methods, namely a method to see the relationship of variables to the object under study is more of a cause and effect, so that in the study there are independent and dependent variables (Sugiyono, 2013).

In this study the population used is all companies listed on the Indonesia Stock Exchange for the period 2013-2017. The sampling technique is nonprobality sampling using purposive sampling method, namely the technique of determining the sample with certain considerations applied based on the research objectives. The variables used in this study are proxied as follows:

Independent Variables (Free Variables)

Profitability

Profitability is the end result of a series of company management policies and decisions (Brigham and Houston, 2009) in Murni (2017). In this study, profitability is measured by Return on Assets. Return on Assets (ROA) is the ratio between net income after tax and total assets. Scale measurement ratio in the form of scale ratio with the following formula (Kasmir, 2017): 
$\mathrm{ROA}=($ Net Income After tax $) /($ Total Assets $)$

Information:

$\mathrm{ROA}=$ Return on Asset

Net Income After Tax $=$ Net income after tax

Total Assets $=$ Total assets

Tax Avoidance

Tax avoidance is an effort made by a company to reduce the tax burden by utilizing the gaps in the laws and regulations. Tax avoidance can be measured using the Book Tax Differences (BTD). Jackson (2009) and Weber (2006) in using the formula for BTD as follows, Syafruddin and Kurniawan (2017):

"BTD" = (Taxable Income-Net Income) / (Average Assets)Information:

$\mathrm{BTD}=$ Tax avoidance

Taxable Income $=$ Pre-tax profit

Net Income $=$ Net profit

Average Assets $=$ Average number of assets at the beginning of the period plus the end of the period

Dependent Variables (Bound Variables)

The dependent variable used in this study is firm value measured by Tobin's Q ratio developed by Chung and Pruit (1994) in Ghozali and Adityamurti (2017). Tobin's Q is measured by the following formula:

["Tobin" \ ^ "'" "s Q =" "MVE + D" / "BVE + D"

Information:

Tobin's Q = Company Value

$\mathrm{MVE}=$ Equity market value (Market Value of Equity), is the multiplication of the market value of shares at the end of the period with the number of shares outstanding at the end of the period.

$\mathrm{BVE}=$ Book Value Equity (Book Value of Equity), is the difference between the total assets of the company with total liabilities.

$\mathrm{D}=$ Book value of total company debt at the end of the period

Intervening Variables (Mediation Variables)

The intervening variable used in this study is earnings management which is measured using discretionary accruals, calculated by the Modified Jones Model as follows (Sulistiawan, et al (2011):

Determine the total accrual value with the formulation:

TAit $=$ NIit - CFOit

Determining the parameter values $\alpha 1, \alpha 2$, and $\alpha 3$ using Jones Model (1991) with the formulation:

TAit $=\alpha 1+\alpha 2 \Delta$ Revit $+\alpha 3$ PPEit + eit

Then to scale the data, all the variables are divided by the assets of the previous year (Ait-1), so that the formulation changes to:

TAit $/$ Ait- $1=\alpha 1(1 /$ Ait- 1$)+\alpha 2(\Delta$ Revit $/$ Ait-1) $+\alpha 3($ PPEit $/$ Ait- 1$)+$ cit

Calculate the NDA value with the formulation:

NDAit $=\alpha 1(1 /$ Ait- $)+\alpha 2(\Delta$ Revit $/$ Ait- $-\Delta$ Recit $/$ Ait- 1$)+\alpha 3($ PPEit $/$ Ait- 1$)$

The parameter values $\alpha 1, \alpha 2$, and $\alpha 3$ are the results of the calculation of step 2 .

Determine the value of discretionary accruals which are accrual earnings management indicators by reducing total accruals with non-discretionary accruals, with the formulation:

DAit $=$ TAit $/$ A it-1 - NDAit

Information:

TAit $=$ Total company accrual $\mathrm{i}$ in period $\mathrm{t}$

NIit = company net profit in period $\mathrm{t}$

CFOit $=$ Company operating cash flow $\mathrm{i}$ in period $\mathrm{t}$

NDA $=$ Nondiscretionary contract of company $\mathrm{i}$ in period $\mathrm{t}$

DAit $=$ Enterprise discretionary accrual $\mathrm{i}$ in period $\mathrm{t}$

Ait-1 $=$ Total company total assets $\mathrm{i}$ in period $\mathrm{t}-1$

$\Delta$ Revit $=$ Change in net sales of company $i$ in period $t$

$\Delta$ Recit $=$ Change in company receivables $\mathrm{i}$ in period $\mathrm{t}$

PPEit $=$ Property, plan and equipment of company $i$ in period $t$

$\alpha 1, \alpha 2, \alpha 3=$ Parameters obtained from the regression equation

$\varepsilon i t=$ Error term of company $i$ in period $t$ 


\section{DISCUSSION}

Descriptive statistics

Descriptive statistical analysis is used to find out descriptive data. This analysis is done by looking at the maximum, minimum, mean and standard deviation values of a data. It is known that the number of samples $(\mathrm{N})$ is 225 data of manufacturing companies, the variables studied are the ratio of profitability (return on assets), tax avoidance (book tax difference), firm value (Tobin's Q) and earnings management (discretional accruals). The results of descriptive statistics in this study are as follows:

\section{Table statistic}

Profitabilitas, Tax Avoidance and profit to company value

\begin{tabular}{lrrrrr}
\hline & N & \multicolumn{1}{c}{ Minimum } & Maximum & \multicolumn{1}{c}{ Mean } & \multicolumn{1}{c}{ Std. Deviation } \\
LN_TOBINSQ & 207 & $-2,16$ & 2,37 &, 3721 &, 72014 \\
DA & 207 &,- 1775 &, 1969 &,- 002715 &, 0665193 \\
LN_ROA & 207 & $-7,77$ & $-1,17$ & $-2,8096$ & 1,24977 \\
LN_BTD & 207 & $-7,43$ & $-2,22$ & $-3,7487$ &, 88115 \\
Valid N (listwise) & 207 & & & &
\end{tabular}

Sumber: Data sekunder yang diolah SPSS 20

The number of samples (N), which is 225 , consists of companies listed on the Indonesia Stock Exchange (IDX) with data for 5 years and those included in the data outliers are 18 samples so that the number of samples (N) becomes 207.

Table statistic

Profitabilitas, Tax Avoidance and profit to company value

\begin{tabular}{|c|c|c|c|c|c|}
\hline & $\mathrm{N}$ & Minimum & Maximum & Mean & Std. Deviation \\
\hline DA & 208 &,- 1775 & , 1969 &,- 002621 & ,0663724 \\
\hline LN_ROA & 208 & $-7,77$ & $-1,17$ & $-2,8020$ & 1,25158 \\
\hline LN_BTD & 208 & $-7,43$ & $-2,22$ & $-3,7418$ & ,88462 \\
\hline Valid N (listwise) & 208 & & & & \\
\hline
\end{tabular}

Sumber: sekunder data yang diolah SPSS 20

The number of samples $(\mathrm{N})$ which is 225 consists of companies listed on the Indonesia Stock Exchange (IDX) with data for 5 years and those included in the data outliers are 17 samples so that the number of samples (N) becomes 208 .

12. Test of Classical Assumptions

a. Normality test

Normality test aims to test whether in the regression model, the interrupting or residual variables have a normal distribution. To get normal data, this study sample used outliers and Ln. The normality test of the data used in this study is the Kolmogorov One-Sample method - Smirnov Test. The way to detect it is to see more than the significance value

Tabel One-Sample Kolmogorov-Smirnov Test Profitabilitas, Tax Avoidance and profit to company value

$\mathrm{N}$

Normal Parameters ${ }^{\mathrm{a}, \mathrm{b}}$

Most Extreme Differences

Kolmogorov-Smirnov Z

Asymp. Sig. (2-tailed)

a. Test distribution is Normal.

b. Calculated from data.
Unstandardized Residual

207

Mean 2,75678567467309E-16

Std. Deviation $\quad, 51403820$

Absolute ,049

Positive ,048

Negative $\quad-, 049$

, 696

Sumber: secondary data SPSS 20

The table above shows the value of the significance level of 0.696 above 0.05 or $5 \%$. This shows that the residual data is normally distributed. 
Tabel One-Sample Kolmogorov-Smirnov Test Profitabilitas, Tax Avoidance and profit to company value

\begin{tabular}{llr}
\hline & & Unstandardized Residual \\
$\mathrm{N}$ & Mean & 208 \\
Normal Parameters & a,b & Std. Deviation \\
& Absolute &, 06565418 \\
&, 061 \\
Most Extreme Differences & Positive &, 061 \\
& Negative &,- 033 \\
Kolmogorov-Smirnov Z & &, 886 \\
Asymp. Sig. (2-tailed) &, 412 \\
a. Test distribution is Normal. & \\
b. Calculated from data. & \\
\hline
\end{tabular}

Sumber: Data sekunder yang diolah SPSS 20

The table above shows the value of the significance level of 0.412 above 0.05 or $5 \%$. This shows that the residual data is normally distributed.

b. Multicollinearity Test

Multicollinearity test aims to test whether the regression model found a correlation between independent variables. A good regression model should not have a correlation between independent variables. Multicollinearity test is seen from the tolerance value and variance inflation factor (VIF). The cut-off value that is commonly used to indicate the presence of multicolonity is to have a Tolerance value of 100.10 or equal to the VIF value of $\geq 10$.

Tabel Uji Multikolonieritas

Profitabilitas, Tax Avoidance and profit to company value Coefficients ${ }^{\mathbf{a}}$

\begin{tabular}{|c|c|c|c|c|c|c|c|}
\hline \multirow[t]{2}{*}{ Model } & \multicolumn{2}{|c|}{ Unstandardized Coefficients } & \multirow{2}{*}{$\begin{array}{c}\text { Standardized Coefficients } \\
\text { Beta }\end{array}$} & \multirow[t]{2}{*}{$\mathrm{t}$} & \multirow[t]{2}{*}{ Sig. } & \multicolumn{2}{|c|}{ Collinearity Statistics } \\
\hline & B & Std. Error & & & & Tolerance & VIF \\
\hline (Constant) & 2,262 &, 168 & & 13,490 &, 000 & & \\
\hline LN ROA & 152 & 045 & 264 & 3,381 & 001 & ,411 & 2,433 \\
\hline LN_BTD & 390 &, 064 & ,477 & 6,122 &, 000 & 413 & 2,423 \\
\hline $\mathrm{DA}^{-}$ &,- 326 &, 548 &,- 030 &,- 594 &, 553 & 978 & 1,022 \\
\hline
\end{tabular}

a. Dependent Variable: LN_TOBINSQ

Sumber: Data sekunder yang diolah SPSS 20

The table above shows the results of the calculation of tolerance values there are no independent variables that have a tolerance value of less than 0.10 . So that it can be concluded that the independent variable is free from the classic assumption of multicolonity.

Table Multicolonity test

Profitabilitas, Tax Avoidance and profit to company value Coefficients $^{\mathrm{a}}$

\begin{tabular}{|c|c|c|c|c|c|c|c|}
\hline \multirow[t]{2}{*}{ Model } & Unstandard & d Coefficients & Standardized Coefficients & $\mathrm{t}$ & Sig. & Collinearity & Statistics \\
\hline & B & Std. Error & Beta & & & Tolerance & VIF \\
\hline (Constant) &,- 025 &, 021 & & $-1,172$ & ,242 & & \\
\hline 1 LN_ROA & 012 & ,006 & ,224 & 2,089 & ,038 & ,41 & 2,401 \\
\hline LN_BTD &,- 015 & ,008 &,- 197 & $-1,843$ &, 067 &, 41 & 2,401 \\
\hline
\end{tabular}

a. Dependent Variable: DA

Sumber: secondary data using SPSS 20

The table above shows the results of the calculation of tolerance values there are no independent variables that have a tolerance value of less than 0.10 . So that it can be concluded that the independent variable is free from the classic assumption of multicolonity.

c. Autocorrelation Test

Aim to test whether in the linear regression model there is a correlation between the confounding errors in period $t$ with the interfering error in period $t-1$ (before). 
Table Autokorelasi

Profitabilitas, Tax Avoidance and profit to company value

\begin{tabular}{|c|c|c|c|c|c|c|c|c|c|}
\hline \multirow[t]{2}{*}{ Model } & \multirow[t]{2}{*}{$\mathrm{R}$} & \multirow{2}{*}{$\begin{array}{c}\mathrm{R} \\
\text { Square }\end{array}$} & \multirow{2}{*}{$\begin{array}{l}\text { Adjusted R } \\
\text { Square }\end{array}$} & \multirow{2}{*}{$\begin{array}{l}\text { Std. Error of } \\
\text { the Estimate }\end{array}$} & \multicolumn{4}{|c|}{ Change Statistics } & Durbin- \\
\hline & & & & & $\begin{array}{l}\text { R Square } \\
\text { Change }\end{array}$ & $\begin{array}{c}\mathrm{F} \\
\text { Change }\end{array}$ & df1 df2 & $\begin{array}{c}\text { Sig. F } \\
\text { Change }\end{array}$ & Watson \\
\hline 1 &, $700^{\mathrm{a}}$ & ,490 & ,483 & ,51782 &, 490 & 65,140 & 3203 &, 000 & ,833 \\
\hline $\begin{array}{l}\text { a. Pred } \\
\text { b. Dep }\end{array}$ & $\begin{array}{l}\text { ictors: } \\
\text { endent }\end{array}$ & $\begin{array}{l}\text { onstant } \\
\text { ariable: }\end{array}$ & $\begin{array}{l}\text { DA, LN_BT } \\
\text { N TOBINS }\end{array}$ & LN_ROA & & & & & \\
\hline
\end{tabular}

Source: secondary data using SPSS 20

Based on the results of the autocorrelation test in table 4.7, it can be explained that the Durbin Watson (DW) number produced is 0.833 , which results are between -2 and $2(-2<0.833<2)$, so it can be concluded that the regression model according to Singgih Santoso in the study this is free from positive autocorrelation and negative autocorrelation.

\section{Table autocorrelation}

Profitabilitas, Tax Avoidance and profit to company value

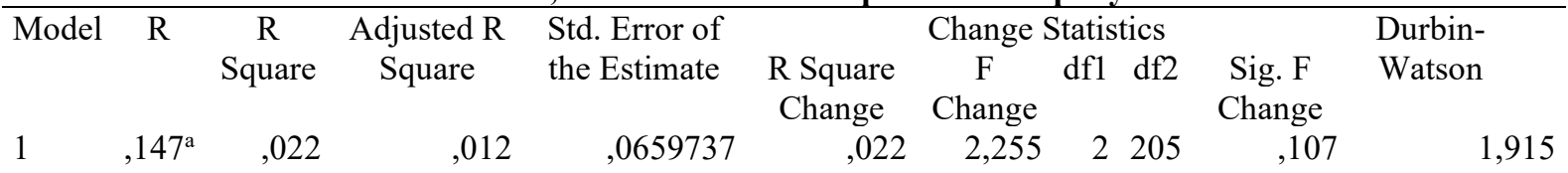

a. Predictors: (Constant), LN_BTD, LN_ROA

b. Dependent Variable: DA

Based on the results of the atabel 4.7 autocorrelation test, it can be explained that the Durbin Watson (DW) number generated is 1.915 which results are between -2 and $2(-2<1.915<2)$, so it can be concluded that the regression model according to Singgih Santoso in the study this is free from positive autocorrelation and negative autocorrelation.

d. Heteroscedasticity Test

Aim to test whether in the regression model variance and residual inequalities occur from one observation to another.

a) Heteroscedasticity test on profitability, tax avoidance and earnings management on firm value, along with the results:

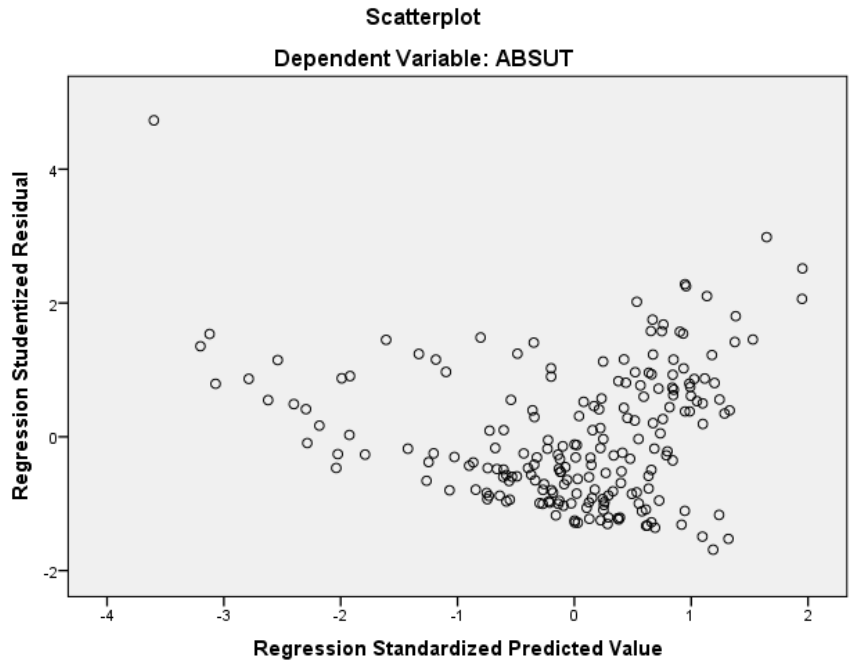

Scatterplot graph

By looking at the picture above, it can be seen that the data spread does not form patterns, overlaps or anything else, so it can be concluded that the data used is free from the problem of heteroscedasticity.

To be more convincing, a linear test is performed by merging the absolute value of the residuals on the dependent variable. The following are the results of the Glesjer Test in this study: 
Source data result

Table Glesjer test

Profitabilitas, Tax Avoidance and profit to company

\begin{tabular}{lr}
\hline \multicolumn{1}{c}{ Variabel } & \multicolumn{1}{c}{ Sig. } \\
LN_ROA &, 086 \\
LN_BTD &, 055 \\
DA &, 191 \\
\hline
\end{tabular}

Based on the results of the linear test in table 4.9 it can be explained that none of the independent variables statistically significant affect the dependent variable ABS_RES (ABSUT). This is because all independent variables have a significant value of more than $5 \%$ so that it can be concluded that the regression model in this study did not occur heteroscedasticity.

b) Heteroscedasticity test on profitability and tax avoidance to earnings management, along with the results:

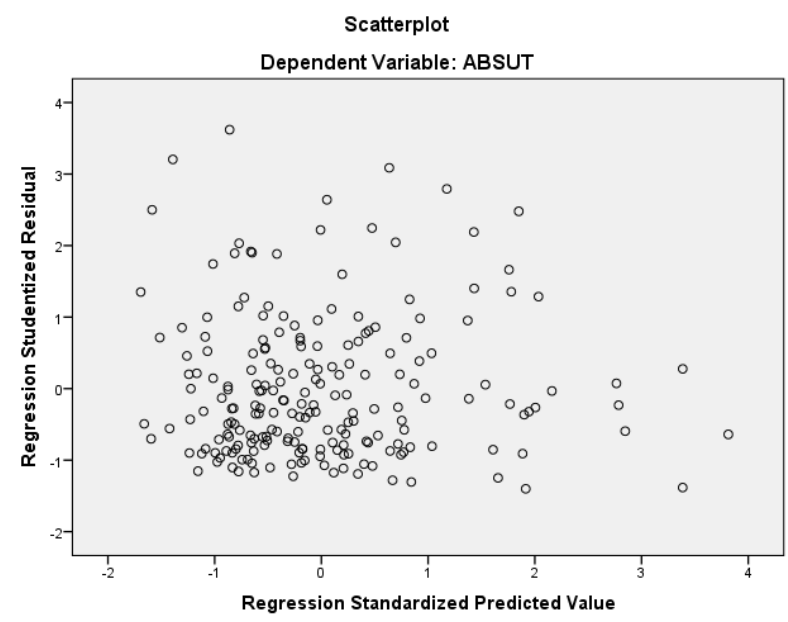

Scatterplot graph

By looking at the picture above, it can be seen that the data spread does not form patterns, overlaps or anything else, so it can be concluded that the data used is free from the problem of heteroscedasticity.

To be more convincing, a linear test is performed by merging the absolute value of the residuals on the dependent variable. The following are the results of the Glesjer Test in this study:

\section{Table Glejer result}

Profitabilitas, Tax Avoidance and profit to company

\begin{tabular}{lr}
\hline Variabel & Sig. \\
LN_ROA &, 812 \\
LN_BTD &, 478 \\
\hline
\end{tabular}

Source data analysis

3. Multiple Regression Analysis

Regression analysis is used to obtain a regression coefficient that will be used to determine the extent to which the relationships between independent variables, dependent variables and intervening variables. Multiple regression analysis is made with 2 equations with the results of the test can be seen in the following table:Equation

$1:$ TOBINSQ $=\alpha+\beta_{1}$ ROA $+\beta_{2}$ BTD $+\beta_{3}$ DATOBINSQ $=2.262+0.152$ ROA +0.39 BTD -0.326 DA

Equation

$2: \mathrm{DA}=\alpha+\beta_{1} \mathrm{ROA}+\beta_{2} \mathrm{BTD}+\varepsilon \mathrm{DA}=-0,025+0,012 \mathrm{ROA}-0,015 \mathrm{BTD}$

4. Model Suitability Test

Determination Coefficient Test (R2)

The Determination Coefficient (R2) is used to measure how far the model's ability to explain

the independent variable.a) Test the coefficient of determination the effect of profitability, tax avoidance and earnings management on firm value 


\section{Table coefisien Determination}

$\begin{array}{rrrr}\text { Model } & \mathrm{R} & \mathrm{R} \text { Square } & \text { Adjusted R Square } \\ 1 & , 700^{\mathrm{a}} & , 490 & , 483\end{array}$

a. Predictors: (Constant), DA, LN_BTD, LN_ROA

b. Dependent Variable: LN_TOBINSQ

Sources : secondary data SPSS 20

Based on the above table it can be seen that the Adjusted R-Square (R2) value of the regression model formed in this study is 0.483 which indicates that the ability of independent variables (ROA, BTD and DA) in explaining the dependent variable of firm value (Tobin's Q) is $48.3 \%$ and the remaining $51.7 \%$ is explained by other causes or variables outside the model.

a) Test the coefficient of determination the effect of profitability and tax avoidance on earnings management

Table Coefisien Determination

Model R R Square Adjusted R Square Std. Error of the Estimate

$1 \quad, 147^{\mathrm{a}}, 022,012$

a. Predictors: (Constant), LN_BTD, LN_ROA

b. Dependent Variable: DA

Source secondary data SPSS 20

Based on the above table it can be seen that the Adjusted R-Square value (R2) of the regression model formed in this study is 0.012 which indicates that the ability of the independent variable (ROA, BTD) in explaining the dependent variable earnings management (DA) is $1.2 \%$ and the remaining $98.8 \%$ is explained by other causes or variables outside the model.

b. Simultaneous Significant Test (Test of F Statistic)

The F Statistic Test basically shows whether all the independent or free variables included in the model have a joint influence on the related dependent variable.

a) Test the simultaneous significant effect of profitability, tax avoidance and earnings management on firm value. Table Signifikcant Simultan test (Uji F)

\begin{tabular}{|c|c|c|c|c|c|}
\hline \multicolumn{6}{|c|}{ ANOVA $^{a}$} \\
\hline Model & Sum of Squares & df & Mean Square & $\mathrm{F}$ & Sig. \\
\hline Regression & 52,400 & 3 & 17,467 & 65,140 &, $000^{\mathrm{b}}$ \\
\hline $1 \quad$ Residual & 54,432 & 203 & ,268 & & \\
\hline Total & 106,832 & 206 & & & \\
\hline
\end{tabular}

a. Dependent Variable: LN_TOBINSQ

b. Predictors: (Constant), DA, LN_BTD, LN_ROA

Source Secondary data using SPSS

Based on the table above, it is known that the $\mathrm{F}$ test test obtained $\mathrm{F}$ count value of 65,140 and a significant value of 0,000 . This calculated $F$ value will be compared with $F$ table. If $k=4$ variables, and $n=207$, then df1 $(\mathrm{k}-1=4-1=3)$ and $\mathrm{df} 2(\mathrm{n}-\mathrm{k}=207-4=203)$ with a $5 \%$ significance level obtained by $\mathrm{F}$ table of 2.65 . Because the probability is $<0.05$ and $F$ count $(65,140)>F$ table $(2,65)$, the model can be used to predict the value of the company or it can be said that ROA, BTD, and DA simultaneously influence the value of the company.

b) Test the simultaneous significant effect of profitability and tax avoidance on earnings management

Table Significant test Simultan (Uji F)

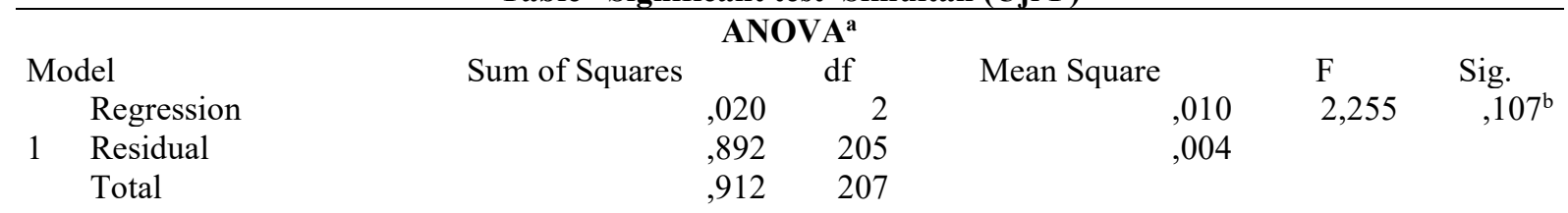

a. Dependent Variable: DA

b. Predictors: (Constant), LN BTD, LN ROA

Source Data analysis using SPSS

Based on the table above, it can be seen that the $F$ test obtained $F$ value of 2.255 and a significant value of 0.107 . This calculated $F$ value will be compared with $F$ table. If $k=3$ variables, and $n=208$, then df1 $(k-1=3-1$ $=2)$ and $\mathrm{df} 2(\mathrm{n}-\mathrm{k}=208-3=205)$ with a $5 \%$ significance level obtained by $\mathrm{F}$ table of 3.04 . Because probability $>$ 0.05 and $\mathrm{F}$ count $(2.255)<\mathrm{F}$ table (3.04), the model cannot be used to predict earnings management or it can be said that ROA and BTD simultaneously do not affect earnings management. 
c. Hypothesis testing

1) Statistical Test Results (t-test)

The $t$ test statistic basically shows how far the influence of one independent variable individually in explaining the variation of the dependent variable (Ghazali, 2013).

Table Statistic Test Result (t-test)

Profitabilitas, Tax Avoidance and profit to company

\section{Coefficients}

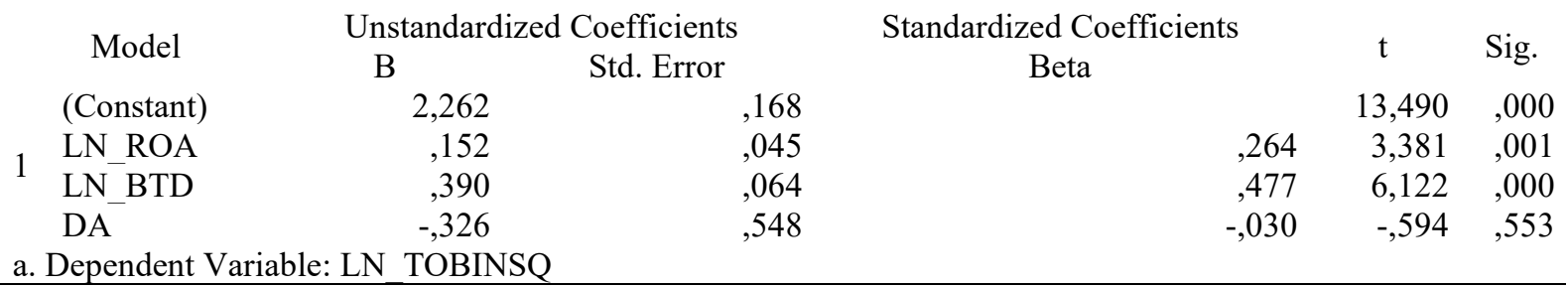

Source : Data secondary using SPSS 20

$\mathrm{T}$ table statistics for a significant level $(\alpha) 5 \% / 2=2.5 \%=0.025$ and $\mathrm{df}$ are $(\mathrm{n}-\mathrm{k}=207-4=203)$ obtained by the $t$ table value of 1.9717 . Based on the table above, it can be concluded that:

a. Variable Return on Assets (ROA) has a significant value of $0.001(0.001<0.05)$ or $t$ count $3.381>t$ table 1.9717 means that hypothesis 1 is accepted. Hal this shows that Return on Assets (ROA) has a significant positive effect on firm value.

b. Tax avoidance (BTD) variables have significant values of $0,000(0,000<0,05)$ or $\mathrm{t}$ count of $6,122>\mathrm{t}$ table 1,9717 means that hypothesis 2 is accepted. Ha1 this shows that tax avoidance (BTD) has a significant positive effect on firm value.

c. The earnings management variable (DA) has a significant value of $0.553(0.553>0.05)$ or $t$ count $-0.594<t$ table 1.9717 means that hypothesis 3 is rejected. Ha1 this shows that earnings management (DA) does not have a significant effect on firm value.

Table Test Result (t-test)

Profitabilitas, Tax Avoidance and profit to company

\section{Coefficients ${ }^{\mathrm{a}}$}

\begin{tabular}{|c|c|c|c|c|c|}
\hline & Unstandardized Coefficients & 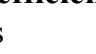 & Standardized Coefficients & & \\
\hline Model & B $\quad$ Std. Error & & Beta & $\mathrm{t}$ & Sig. \\
\hline (Constant) &,- 025 & 021 & & $-1,172$ & 242 \\
\hline 1 LN_ROA &, 012 & 006 & 224 & 2,089 & 038 \\
\hline LN_BTD &,- 015 & ,008 &,- 197 & $-1,843$ & 067 \\
\hline
\end{tabular}

\section{Source Secondary data using SPSS 20}

The $\mathrm{t}$ table statistic for a significant level $(\alpha) 5 \% / 2=2.5 \%=0.025$ and $\mathrm{df}$ is $(\mathrm{n}-\mathrm{k}=208-3=205)$ obtained $\mathrm{t}$ table value of 1.9716. Based on the table above, it can be concluded that:

a. Variable Return on Assets (ROA) has a significant value of $0.038(0.038<0.05)$ or $t$ count $2.089>t$ table 1.9716 means that hypothesis 1 is accepted. Hal this shows that Return on Assets (ROA) has a significant positive effect on earnings management.

b. Tax avoidance (BTD) variable has a significant value of $0.067(0.067>0.05)$ or $\mathrm{t}$ count $-1.843<\mathrm{t}$ table 1.9716 means that hypothesis 2 is rejected. Hal this shows that tax avoidance (BTD) does not have a significant effect on earnings management.

2) Mediation Test (Intervening)To do direct and indirect calculations performed from the standardized regression coefficient value of each independent variable on the dependent variable and path analysis images can also be made as follows:

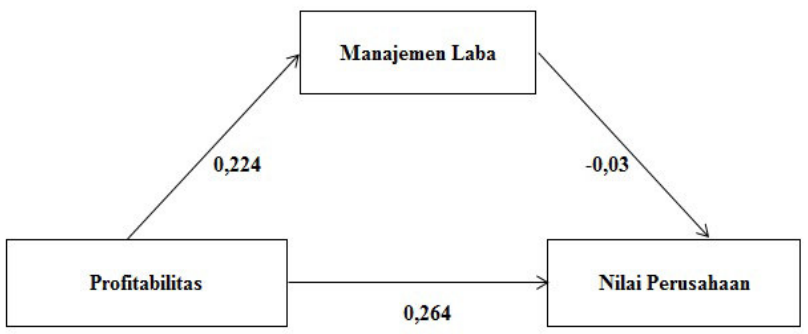

Line analysis 1 


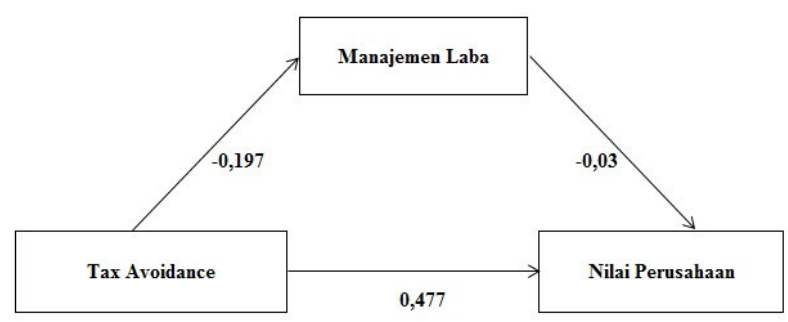

Line Analysis 2

The magnitude of the error value for each influence of the independent variable on the dependent is obtained through the following calculations:

Pe $1=\sqrt{ } 1-0,7002=0.714$

$\operatorname{Pe} 2=\sqrt{ } 1-0.1472=0.989$

In the trimming category testing the validity of the research model is observed through the calculation of the total determination coefficient:

$\mathrm{R}^{2} \mathrm{~m}=1-\mathrm{Pe}^{2}{ }_{1} \mathrm{Pe}^{2}{ }_{2} \ldots . \mathrm{Pe}^{2} \mathrm{p}$

$=1-(0,714)^{2}(0,989)^{2}$

$=1-(0,509)(0,978)$

$=0,502$

$=50,2 \%$

The coefficient of determination of $50.2 \%$ shows that $50.2 \%$ of the information contained in the data can be explained by the model, while the remaining $49.8 \%$ is explained by errors and other variables outside the model. The number of coefficients on this model is relatively large so that it is worth doing further interpretation.

a) Analysis of the effect of profitability on firm value through earnings management

In the path analysis picture known the direct effect of profitability on firm value 0.264 while the indirect effect of profitability on firm value through earnings management is the multiplication between the value of beta ROA and DA with the beta DA value of TOBINSQ, namely: $0.224 \times-0.03=0.007$. Based on the results of these calculations, it is known that the direct effect value is 0.264 and indirect effect is 0.007 which means that the value of direct influence is greater than the value of indirect influence. This result shows that variable earnings management cannot mediate between profitability and firm value.

b) Analysis of the effect of tax avoidance on firm value through earnings management

In the path analysis picture, it is known that the direct effect of tax avoidance on firm value is 0.477 while the indirect effect of tax avoidance on firm value through earnings management is the multiplication of beta BTD values against DA with beta DA values against TOBINSQ, namely: $0.477 \times-0.03=-0.014$. Based on the results of these calculations, it is known that the direct effect value is 0.477 and the indirect effect is -0.014 which means that the value of direct influence is greater than the value of indirect influence. This result shows that variable earnings management cannot mediate between tax avoidance and firm value.

\section{DISCUSSION}

1. Effect of profitability on company value

Based on the results of research Return on Assets (ROA) has a significant positive effect on firm value. Thus hypothesis 1 is accepted which means that if ROA increases, the value of Tobin's Q will increase. Conversely, if ROA decreases, Tobin's Q will decrease. Increasing the value of ROA shows a good picture in the future, because ROA shows the rate of return on investment given by the company by using all assets owned by the company. A high return will be responded positively by investors so that the value of the company will increase. The results of this study are in line with the research of Wulandari and Suryono (2018) and Normayanti (2017) who found that profitability has a positive effect on firm value. But it contradicts the research conducted by Ananda (2017) who found that profitability does not affect the value of the company.

2. Effect of tax avoidance on firm value

Based on the results of tax avoidance (BTD) research, it has a significant positive effect on firm value. Thus hypothesis 2 is accepted which shows that the higher tax avoidance (BTD), the company value will increase. This is because in Indonesia, tax avoidance is seen as an advantage for the company rather than seeing it as a risk that can be borne by the company. The company considers that there is no better expenditure savings than tax avoidance. By doing tax avoidance, the tax paid by the company will be small and the company's profits to be distributed to investors can be large and can increase the value of the company. The results of this study are in line with the research of Syafruddin and Kurniawan (2017), Pradnyana and Noviari (2017) who found that tax avoidance has an effect on firm value. But it contradicts the research conducted by Ghozali and Adityamurti (2017) and Yuyetta and Winasis (2017) who find that tax avoidance does not affect the value of the company. 
3. Effect of profitability on earnings management

Based on the results of the research Return on Assets (ROA) has a significant positive effect on earnings management. Thus hypothesis 2 is accepted so that it can be said that the increasing value of ROA can indicate high earnings management practices. The company's performance is getting better in the eyes of investors seen from the maximization of profits that can be generated by the company. Management is encouraged to practice earnings management, because management wants to show good performance to investors in earning profits through company assets. In addition, investors are also more interested in investing in companies with stable and high profits, so that when the profitability of the company is low, managers generally take earnings management actions to save their performance in the eyes of the owner. The results of this study are in line with the research of Murni (2017), Kamil and Ariyani (2017) and Dewi and Priyadi (2016) who find that profitability affects earnings management. The results of this study also contradict Saputra (2016), Rachman (2015) and Gunawan et al. (2015) who find that profitability does not affect earnings management.

4. Effect of tax avoidance on earnings management

Based on the results of tax avoidance (BTD) research the effect does not affect the value of the company. Thus hypothesis 4 is rejected which shows that the amount of tax paid by the company does not affect management to do earnings management. This can be caused due to various underlying conditions, including company policies, company regulations or other factors. The results of this study are in line with the research of Husain (2017) who found that tax avoidance does not affect earnings management. However, this study is not in line with the research of Larastomo et al. (2016) which found that tax avoidance has an effect on earnings management.

5. Effect of earnings management on firm value

Based on the results of research on earnings management (DA) does not affect the value of the company. Thus hypothesis 5 is rejected, so that it can be said that by increasing the management of food profit it will not be followed by an increase in the value of the company. The results of this study found that when the objectives held between the manager and the owner of capital differed, the conflict would occur, because the owner of the capital would feel cheated by the manager who committed accounting fraud. The results of this study support the results of the research of Verawaty et al (2017) and Lestari and Ningrum (2018) which state that earnings management has no influence on firm value. However, the reverse research was conducted by Arhdum et al (2017), Febyani and Devie (2017) and Abdallah and Suryani (2018) which stated that earnings management had an effect on the value of the company.

6. Effect of profitability on company value through earnings management

Based on the results of research Return on Assets (ROA) does not affect the value of the company through earnings management. Thus hypothesis 6 is rejected which investors usually prefer to invest in companies whose earnings are stable or high and tend not to see how much return on investment from assets managed by the company. Thus, when a low or high ROA does not affect the investor's decision to invest. When the value of ROA is not as expected by the shareholders, management will be motivated to do earnings management so that management performance looks good in the eyes of investors, but it does not affect investors to withdraw their investment or not invest because some investors consider it already commonplace. This is consistent with the results of research conducted by Hermanto, et al (2018) which states that the addition of earnings management variables cannot be stated as an intervening variable.

7. Effect of tax avoidance on firm value through earnings management

Based on the results of tax avoidance research does not affect the value of the company through earnings management. Thus hypothesis 7 is rejected because investors usually prefer to invest in companies with stable or high profits and tend not to see how much tax is paid by company. When managers do earnings management by doing tax avoidance, it does not affect investors decisions to invest. So that investors will not withdraw their investment or not invest even though the company does tax avoidance and earnings management because it is considered by some investors to be normal. This is consistent with the results of research conducted by Hermanto, et al (2018) which states that the addition of earnings management variables cannot be stated as an intervening variable.

\section{CONCLUSIONS AND SUGGESTIONS}

Conclusion

The test results and discussion in the previous section can be summarized as follows:

1) Profitability has a significant positive effect on firm value. This shows that the higher profits obtained by the company will increase the value of the company.

2) Tax avoidance has a significant positive effect on firm value. This shows that the smaller the tax paid will increase the value of the company.

3) Profitability has a significant positive effect on earnings management. This shows that the increasing value of ROA can indicate high earnings management practices. The company's performance is getting better in the eyes of investors seen from the maximization of profits that can be generated by the 
company. Management is encouraged to practice earnings management, because management wants to show good performance to investors in earning profits through company assets. In addition, investors are also more interested in investing in companies with stable and high profits, so that when the profitability of the company is low, managers generally take earnings management actions to save their performance in the eyes of the owner.

4) Tax avoidance does not affect earnings management. This shows that the amount of tax paid by the company does not affect management to do earnings management. This can be caused due to various underlying conditions, including company policies, company regulations or other factors.

5) Earnings management does not affect the value of the company. This shows that the increase in food profit management will not be followed by an increase in firm value. The results of this study found that when the objectives held between the manager and the owner of capital differed, the conflict would occur, because the owner of the capital would feel cheated by the manager who committed accounting fraud.

6) Profitability does not affect the value of the company through earnings management. This shows that investors usually prefer to invest in companies whose earnings are stable or high and tend not to see how much return on investment from assets managed by the company. Thus, when a low or high ROA does not affect the investor's decision to invest. When the value of ROA is not as expected by the shareholders, management will be motivated to do earnings management so that management performance looks good in the eyes of investors, but it does not affect investors to withdraw their investment or not invest because some investors consider it already commonplace.

7) Tax avoidance does not affect the value of the company through earnings management. This shows that investors usually prefer to invest in companies with stable or high profits and tend not to see how much tax is paid by the company. Thus, when managers carry out earnings management with tax avoidance on companies it does not affect investors' decisions to invest. So that investors will not withdraw their investment or not invest even though the company does tax avoidance and earnings management because it is considered by some investors to be normal.

1. Investors who will invest should not only look at the Return on Assets (ROA) ratio because there are still many other financial ratios such as: Dividend Payout Ratio, Debt Equity Ratio, Current Ratio, Quick Ratio, Market to book ratio, Earning Per Share, Return on Equity, Net Profit Margin, Total Asset Turnover, Price Earning Ratio. Investors need to consider the possibility of financial report manipulation carried out by management, because one of the motives of management to manage earnings is to attract investors to invest.

2. Researchers in this study use independent variables of profitability (ROA) and tax avoidance (BTD), and further research can use other proxies than those already used in this study or can also add corporate governance variables that have many proxies including institutional ownership, ownership managerial, independent commissioner and committee

\section{REFERENCE}

Abdallah, Zachari \& Suryani, Dewi (2018). Pengaruh Manajemen Laba Terhadap Nilai Perusahaan dengan Kualitas Audit Sebagai Variabel Pemoderasi. JIPI, Vol. 2, No. 1, hal 16-29, e-ISSN 2598-067x

Alexander, Nico \& Hengky (2017). Factors Affecting Earning Management in the Indonesian Stock Exchage. Journal of Finance and Banking Review, Vo. 2, No. 2, PP 8-14, ISSN 0128-3103.

Ananda, N.A. (2017). Pengaruh Profitabilitas dan Struktur Modal Terhadap Nilai Perusahaan. Jurnal Ekonomi dan Bisnis Indonesia, Vol. 02, No. 01 pp 25-31

Arhdum, Z., Taufik, Taufeni. \& Ratnawati, Vince. (2017). Pengaruh Earning Mangement dan Corporate Sosial Responsibility Terhadap Nilai Perusahaan Dengan Mekanisme Good Corporate Governance Sebagai Variabel Moderasi. Jurnal Akuntansi, Vol. 6, No. 1, hal 100-118, ISSN 2337-4314.

Ariyani, Meiliyah., \& Kamil, Islamiah. (2017). Manajamen Laba Ditinjau Dari Faktor Beban Pajak Tangguhan, Profitabilitas dan Leverage. Jurnal Online Insan Akuntansi, Vol. 2, No. 2, hal 259-270, E-ISSN 2528-0163

Asih, P. (2014) "Faktor-Faktor yang Mempengaruhi Praktik Manajemen Laba (Studi Kasus: Perusahaan Manufaktur yang Terdaftar di BEI)". Jurnal Tekun, Volume V, No 02. ISSN 191-201

Cheryta, A.M., Moeljadi \& Indrawati, N.K. (2017). The Effect of Leverage, Profitability, Information Asymmetry, Firm Size on Cash Holding and Form Value of Manufacturing Listed at Indonesia Stock Exchage. International Journal of Research in Business Studies and Management, Vol. 4, Issue 4, ISSN 2394-5923 (Print) \& ISSN 2394-5931 (Online).

Dewi, R.P. \& Priyadi, M.P. (2016). Pengaruh Free Cash Flow, Kinerja Keuangan Terhadap Earnings Management Dimoderasi Corporate Governance. Jurnal Ilmu dan Riset Akuntansi, Vol. 5, No. 2, ISSN 2460-0585 
Dyreng, S. D., Hanlon, M. \& Maydew, E. L. (2008) “Long-Run Corporate Tax Avoidance”. The Accounting Review, Vol 83, No 1, page 61-82

Febyani, Estrella \& Devie (2017). Pengaruh Kepemilikan Manajerial Terhadap Nilai Perusahaan Melalui Manajemen Laba Sebagai Variabel Intervening. Business Accounting Review, Vol. 6, No. 2, hal 745-756

Ghozali, Imam \& Latan, Hengky (2015). Partial Least Square; Konsep, Teknik dan Aplikasi Menggunakan Program SmartPLS 3.0 Edisi 2. Semarang: Universitas Diponegoro

Ghozali, Imam dan Adityamurti, Enggar (2017). Pengaruh Penghindaran Pajak dan Biaya Agensi Terhadap Nilai Perusahaan. Diponegoro Journal of Accounting, Vol. 6, No. 3, Hal 1-12, ISSN (online) 2337-3806.

Hermanto, W., Kamaliah \& Rasuli. (2018). Pengaruh Struktur Kepemilikan Terhadap Nilai Perusahaan dengan Manajemen Laba sebagai Variabel Mediasi. Procuratio, Vol. 6 No. 1, hal 54-65, e-ISSN 2580-3743

Jensen, Michael C., \& Meckling, William H. (1976). Theory of the Firm: Managerial Behavior, Agency Costs and Ownership Structure. Jurnal of Financial Economics, October, 1976, B. 3, No. 4, PP 305-360.

Kasmir, (2017). Analisis Laporan Keuangan, Jakarta: Rajawali Pers

Kurniasih, T., \& Sari, M.M.R. (2013). Pengaruh Return on Assets, Laverage, Corporate Governance, Ukuran Perusahaan dan Kompetensi Rugi Fiskal pada Tax Avoidance. Buletin Studi Ekonomi, Vol 18, No 1, hal 5866. ISSN 1410-4628.

Larastomo, J., Perdana, H. D., Triatmoko, H., \& Sudaryono, E. A. (2016) "Pengaruh Tata Kelola Perusahaan dan Penghindaran Pajak Terhadap Manajemen Laba pada Perusahaan Manufaktur di Indonesia”. Jurnal Bisnis dan Manajemen, Vol 6, No 1, hal 63-74. ISSN 2461-1182

Letasri, Nanik \& Ningrum, S.A. (2018). Pengaruh Manajemen Laba dan Tax Avoidance terhadap Nilai Perusahaan dengan Kualitas Audit sebagai Variabel Moderasi. Jurnal of Applied Accounting and Taxation, Vol. 3, No. 1, PP 99-109, e-ISSN 2548-9925

Minanari, Profita 2018 Pengaruh

Profitabilitas, Manajemen Laba dan

Kebijakan Deviden terhadap Nilai

Perusahaan (Studi Empiris pada

Perusahaan Manufaktur yang Terdaftar di

Bursa Efek Indonesia Periode 2015-2016)

Murni, Seri (2017). Pengaruh Arus Kas Bebas, Profitabilitas, Ukuran Perusahaan dan Leverage Terhadap Manajemen Laba. Jurnal Hukum Islam, Perundang-undangan dan Pranata Sosial, Vol, VII, No. 1, ISSN 2088-9712 dan E-ISSN 977-2580536

Normayanti, (2017). Pengaruh Kebijakan Hutang, Kebijakan Dividend dan Profitabilitas Terhadap Nilai Perusahan. eJournal Administrasi Bisnis, Vol. 5 No. 2, hal 376-389, ISSN 2355-5408

Pradnyana, I.B.G.P., \& Noviari, Naniek. (2017). Pengaruh Perencanaan Pajak Terhadap Nilai Perusahaan dengan Transparansi Perusahaan Sebagai Variabel Moderasi. E-Jurnal Akuntansi Universitas Udayana, Vol. 18, No. 2, hal 1398-1425, ISSN 2302-8556

Putri, R.H., Zahroh, Z.A., \& Endang, M.G.W.N.P. (2016). Pengaruh Rasio Likuiditas dan Rasio Profitabilitas Terhadap Nilai Perusahaan. Jurnal Administrasi Bisnis (JAB), Vol. 38, No. 2.

Rachman, Taufiqur. 2015). Pengaruh Proporsi Komisaris Independen, Free Cash Flow, ROA dan Perputaran Aset Terhadap Praktek Manajemen Laba. Jurnal Akuntansi UNESA, Vol. 4, No. 1

Santa, S.L.L \& Rezende, A.J. (2016). Corporate tax avoidance and firm value: from Brazil. Revista Contemporanea de Contabilidade, Vol. 13, No. 30, PP 114-133, ISSN 2175-8069.

Santoso, Singgih (2012). Paduan Lengkap SPSS Versi 20. Jakarta: PT. Elex Media Komputindo

Saputra, T.A. (2016). Analisis Faktor- Faktor yang Berpengaruh Terhadap Manajemen Laba. Makro, Jurnal Manajemen \& Kewirausahaan, Vol. 1, No. 1, ISSN 1412-2936

Sari, R.A.I. \& Priyadi, M.P. (2016). Pengaruh Leverage, Profitabilitas, Size, dan Growth Opportunity Terhadap Nilai Perusahaan. Jurnal Ilmu dan Riset Manajemen, Vol. 5, No. 10, ISSN 2461-0593

Solimun, (2011) dan Hari et.al., (2010). Program Studi Statistika FMIPA UB.

Sucuachi, William \& Cambarihan, J.M (2016). Influence of Probability to the Firm Value of Diversifies Companies in the Philippines. Accounting an Finance Research, Vo. 5, No. 2, ISSN 1927-5986, E-ISSN 1927-5994

Sugiyono. (2013) “Metodologi Penelitian Bisnis". Bandung: Alfabeta

Sulistiawan, D., Januarsi, Y. \& Alvia, L. (2011). Creative Accounting: Mengungkap Manajemen Laba dan Skandal Akuntansi. Malang: Salemba Empat.

Syafruddin, M. \& Kurniawan, A.F. (2017). Pengaruh Penghindaran Pajak Terhadap Nilai Perusahaan dengan Variabel Moderasi Transparasi. Diponegoro Journal of Accounting, Vol. 6, No. 4, hal 1-10, ISSN (online) 2337-3806.

Tarima, G., Parengkuan, T., Untu, V. (2016). Pengaruh Profitabilitas, Keputusan Investasi dan Keputusan Pendanaan terhadap Nilai Perusahaan Farmasi yang Terdaftar di BEI Periode 2011-2014. Jurnal Berkala 
Ilmiah Efesiensi, Vol. 16, No. 4.

Tjandrakirana, R. \& Monika, Meva. (2014). Pengaruh Kinerja Keuangan Terhadap Nilai Perusahaan Pada Perusahaan Manufaktur Yang Terdaftar di Bursa Efek Indonesia. Jurnal Manajemen \& Bisnis Sriwijaya, Vol. 12, No. 1, ISSN 1412-4521

Verawaty., Merina, C.I., \& Lastari, S.A. (2017). Pengaruh Intellectual Capital, Earnings Management, Tax Avoidance Terhadap Nilai Perusahaan dengan GCG sebagai Pemoderasi. Jurnal Ilmiah MBiA, Vol. 16, No. 2, hal 79-94.

Wulandari, N.E. \& Suryono, B. (2018). Pengaruh Struktur Modal, Ukuran Perusahaan dan Profitabilitas Terhadap Nilai Perusahaan. Jurnal Ilmu dan Riset Akuntansi, Vol. 7, No. 1, hal 1-17, e-ISSN 2460-0585

Yorke, S.M., Amidu, M., \& Boateng, A.B. (2016). The effect of earning management and corporate tax avoidance on firm value. International Jurnal of Management Practice, Vol. 9, No. 2, PP 11-131.

Yuyetta, E.N.A. \& Winasis, S.E. (2017). Pengaruh Gender Diversity Eksekutif Terhadap Nilai Perusahaan, Tax Avoidance sebagai Variabel Intervening: Sudi Kasus Pada Perusahaan Pertambangan yang Terdaftar di BEI Tahun 2012-2015. Diponegoro Journal of Accounting, Vol. 6, No. 1, hal 1-14, ISSN (online) 2337-3806 www.idx.co.id www.sahamok.com www.finance.yahoo.com 